\title{
A Knapsack Full of Dreams: Memoirs of a Street Nurse
}

\section{Cathy Crowe}

354 pages, $\$ 48.50$

Victoria, BC: FriesenPress, 2019

ISBN 9781525534539

Reviewed by Natalie Stake-Doucet, RN Nurse Activist and President Quebec Nurses Association, Canadian Nurses Association Board Member Quebec Representative Montreal, QC

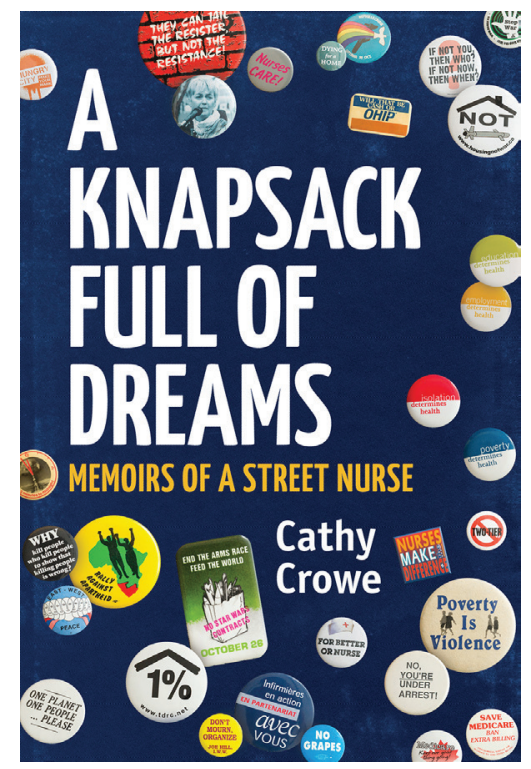

\begin{abstract}
A Knapsack Full of Dreams: Memoirs of a Street Nurse, published by FriesenPress in 2019, is an engaging nursing read. The author, Cathy Crowe, is well known for her activism against homelessness and has received many commendations and awards for her work, along with five different honorary doctorates from various Canadian universities. This autobiography offers a critical historical perspective on the evolution of Canadian healthcare from the 1970 s until today.
\end{abstract}

\section{One Nurse's Fight for Social Justice}

Crowe graduated from the Toronto

General Hospital School of Nursing in 1972. This book is her story, which is embedded in the political and social issues that inform her nursing practice - whether direct nursing care or "nursing politics," as she calls it.

Crowe's activism is rooted in the front lines, but she has also lobbied politicians and decision makers, sometimes in a formal setting and sometimes by storming public council meetings or government offices. She has been arrested more than once, yet she also received the Order of Canada in 2018.

\section{Real-Life Consequences}

Crowe's book is divided into 20 chapters, each beginning with a short synopsis of a film that she relates to the issues raised in that chapter. Although 
"She has been arrested more than once, yet she also received the Order of Canada in 2018."

each chapter could almost stand alone, together they tell the story of the reallife consequences of the rise of neoliberalism in Toronto and beyond, from the 1980s on. Crowe deftly shows us the human costs of cutbacks to welfare, the always more precarious financing of community organizations and the people who fight for a more just society.

For example, Chapter 6 describes the 1995 movie Dead Man Walking, a film about a nun's fight to end the death penalty. Crowe relates to the character of Sister Helen Prejean, played by Susan Sarandon. She explains that when she began working as a street nurse, many assumed she aspired to be like Mother Teresa. But Crowe's street nursing was not born from a sense of religious duty or an act of charity.

Crowe explains that nurses like her, and to some degree even religious groups, are often misunderstood in their work. For example, the Sisters of Providence in Kingston, Ontario, who engage in non-violent actions on social issues that affect the most vulnerable, do both "upstream work" (improving social and economic structures that keep people from achieving optimal health) and "downstream work" (interventions and strategies to provide equitable access to care and services and mitigate the negative impacts of disadvantage on health) (NCCDH 2020).
Crowe recalls a particularly effective political campaign against the return of the death penalty in Canada, led by a number of church groups and civilian organizations. The slogan was, "Why kill someone to show that killing people is wrong?" - a simple, yet clear, slogan that pointed to the absurdity of the death penalty.

In contrast, nursing and medical professional organizations were absent from the campaign against the death penalty. Crowe explains how they have historically avoided addressing social policies instead of treating them as public health issues. Although few nursing organizations have participated in social justice movements, many individual nurses have taken a stand. Among the examples cited by Crowe is Marion Dewar, the public health nurse-turned-mayor of Ottawa who launched a campaign in 1979 to find sponsors in her city for 4,000 Vietnamese refugees (p. 7).

\section{From Private Nursing to Activism}

This book is a testament to nurses' unique and extraordinarily rich perspective on society and the human condition. Crowe's account of her professional life - from private nursing in a fancy office in Toronto's financial district, to hospital nursing, to street nursing and nursing activism - is effortlessly framed in the socio-political context of her nursing.

Crowe reminds us that despite what she learned in nursing school, nursing is inherently political. From 
cardiovascular health to addiction, everything has its social context. She cites examples from Ontario, where the privatization of food services in healthcare resulted in decreased nutrition and slowed healing in patients (p. 31), and cutbacks in welfare during the 1990s led to an increase in homelessness and an alarmingly high death toll in the winter of 1997 (pp. 135-60).

Crowe's rising panic and distress at those deaths, while governments did nothing, will remind many nurses of the current opioid epidemic and how society and social programs do not value all lives equally. Her scathing critique of one such program, the federal Housing First initiative, is reason enough to read this book. She dedicates all of Chapter 19 ("Under the Rug: Housing First Inhuman 'Solution' to Homelessness and Its Terrible Legacy") to a detailed description of the rise of the program and its impact on the people it was supposed to help (pp. 285-301).

\section{The Meaning of Nursing}

Throughout her book, Crowe constantly reminds us what it means to be a nurse. What is nursing? How do we define it? These questions continue to elicit passionate debates among nurses in all sectors, from academia to the bedside.

With this book, Crowe reconciles what is often dichotomized in our field: activism and policy making. She is an expert at developing a movement, including through protests and civil
"Crowe constantly reminds us what it means to be a nurse. What is nursing? How do we define it?"

disobedience, yet she is also able to bring the strength of that movement with her when she meets formally with politicians and decision makers.

The political work that Crowe does, whether leafleting at a street corner or meeting an important city administrator, is seamless. However, the skills she has acquired over the years did not come from nursing school but from nursing work. She states, "I remain frustrated at what I did not learn in nursing school. Teachings that would support political and economic literacy were appallingly absent" (p. 304). Although nursing school allowed her to get her licence, it was not the nursing school that made her a nurse.

Nursing school is a double-edged sword; it gives us the keys to a world in which social inequalities and class society are clearer than anywhere else, but nursing training also "[crushes] independence" (p. 196). Crowe does not shy away from describing how disconnected our healthcare system is, including nursing, from the realities of capitalist society. If, despite the "crushed independence" of nursing school, we are still capable of producing nurses of Crowe's calibre, imagine what we might achieve if we were to teach critical theory and politics in nursing schools across Canada. 
This book makes us dream, makes us think and - most of all - makes us restless. Nurses need more books like this. I just hope our next nurse activist books have an index!

Correspondence may be directed to: Natalie Stake-Doucet via e-mail atnatalie.stake-doucet@umontreal.ca.

\section{Reference}

National Collaborating Centre for Determinants of Health (NCCDH). 2020. Upstream/

Downstream. Retrieved September 21, 2020. $<$ http://nccdh.ca/glossary/entry/upstreamdownstream $>$.

\section{RESPONDING TO THE COVID CRISIS}

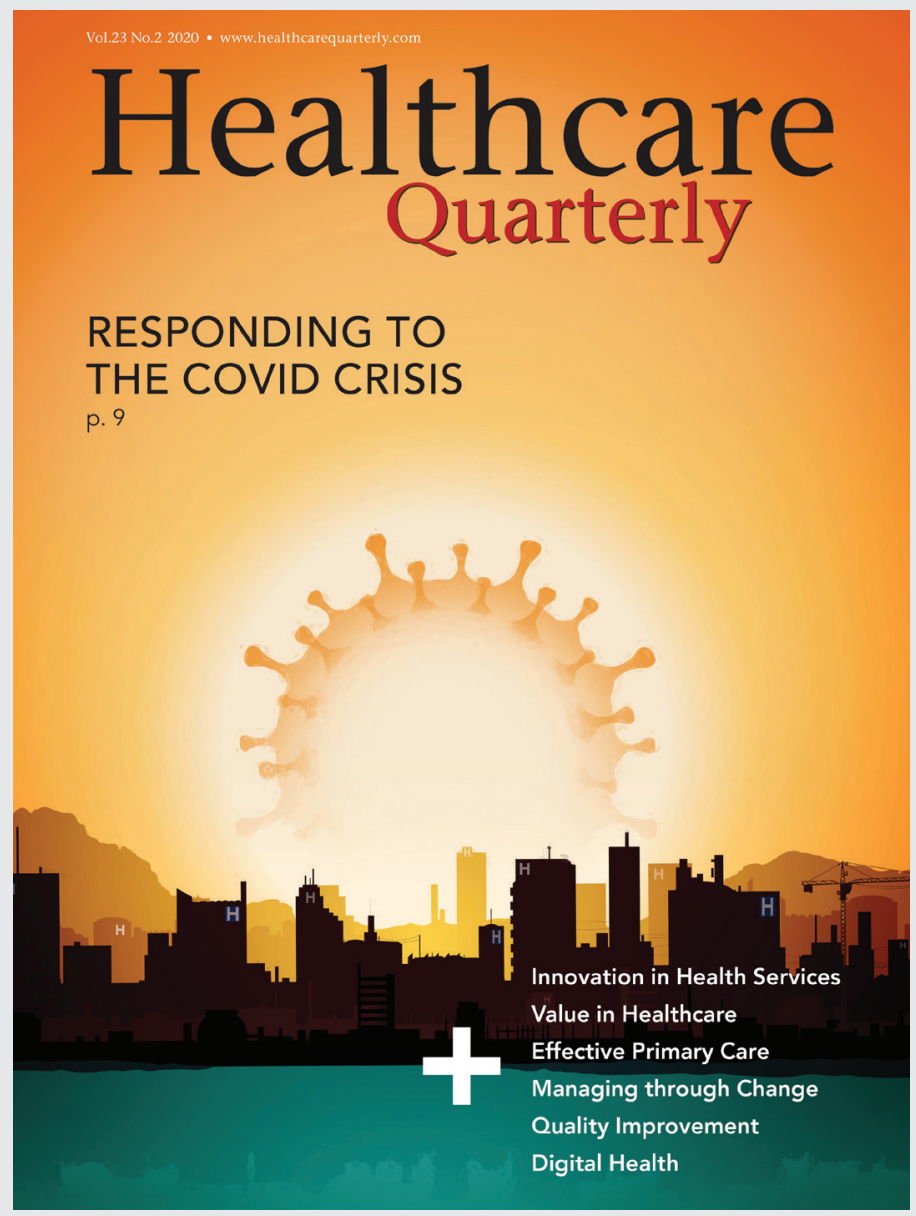

FIND IT AT HEALTHCAREQUARTERLY.COM 